\title{
12
}

\section{The Case for}

Sophisticated Course Syllabi

\section{Michael J. Strada}

West Virginia University and West Liberty State College

Just as the last thing a fish would notice is water, academics tend to overlook the value of a comprehensive course syllabus. It seems too prosaic for some instructors to take seriously. Despite operating largely in obscurity, a nascent body of literature appreciative of the syllabus' latent potential is emerging. The distinguishing features of model syllabi are traced here, and their respective benefits analyzed. First and foremost, good syllabi enhance student learning by improving the way courses are taught. But the potential of syllabi can also be tapped by using them more prominently in the faculty evaluation process. Much slower to develop has been an awareness of howe exemplary syllabi can forge substantive links among three curricular levels of the academy often proceeding randomly: individual courses, programs of study at the departmental level, and general studies requirements at the institutional level. The assessment movement now sweeping American higher education can broaden its analytical base by recognizing the exemplary syllabus as a rare fulcrum uniting each of the three academic levels pursuing institutional mission statements.

\section{Scope of the Problem}

R obert Diamond, a widely quoted analyst of American higher educa$\mathbf{R}_{\text {tion, surveys the literature relating individual courses and institu- }}$ tional curricula and arrives at some unsettling conclusions. Specifically, Diamond decries the prevalence of courses designed with little or no relationship to the curriculum that is in place or to the critical skills students need to acquire, courses of study that are more serendipitous than planned, and higher education curricula that do not produce the results we intend (Diamond, 1998, p. 2). 
I believe that one of the tools vital for attacking the problems cited by Diamond is a rigorous course syllabus. But just as the last thing a fish would notice is water, academics often overlook the value of a comprehensive syllabus. Indicative of the low status accorded to the syllabus in academe, no substantial body of literature exists on the subject because it seems too prosaic for sustained inquiry. However, students, professors, and curricular integrity would all benefit if institutions decided to uncork the latent potential of the syllabus, since the bloodless course outline sometimes passing as a syllabus is no more than a caricature of the genuine article.

The inadequacy of some course syllabi received considerable attention in a 1985 article that appeared in the Chronicle of Higher Education. Sharon Rubin's report on the findings of a course approval committee at the University of Maryland shed light on this nearly invisible phenomenon. Her faculty committee found a series of pivotal questions unanswered by most of the course syllabi that students received from their professors, such as Why should a student want to take this course? Why do the parts of the course come in this particular order? Will it consist mostly of lecture, discussion, or group work? What skills or knowledge will the tests test? Why have these specific books been chosen? Rubin paints a bleak portrait of her exposure to scores of weak course syllabi. She says that the worst ones fell into two groups: the listers-those whose bare-bones outlines tell what is to be read and done, but without any hint of the principles behind the course; and the scolders-those who read more like caveats from a defense lawyer than heuristic tips from a professor, by detailing the consequences of myriad misbehaviors. The scolders seem intent on practicing defensive pedagogy in a litigious age. Overall, Rubin concludes that the pervasiveness of inadequate syllabi symbolizes an unhealthy deterioration of communication between teachers and students. Such poor communication must seem worrisome to Howard Altman and William Cashin, who write elsewhere that the primary purpose of a syllabus is to communicate to one's students what the course is about, why it is taught, where it's going, and what will be required of them to complete it successfully (Altman \& Cashin, 1992, p. 3).

The good things accompanying the metamorphosis from weak twopagers to dense, thoughtful ten-pagers, are well-kept secrets. Faculty seldom champion the value of the course syllabus-a document considered destined for student eyes only. The time-honored principle of academic freedom also exacerbates the problem of the underachieving syllabus by shielding against unsolicited interference into the sanctity of the professor's classroom space. When this happens, faculty isolation and resistance 
to change naturally result. Another contributing factor is psychological denial on the part of some professors. I have heard colleagues remark that a ten-page syllabus qualifies as an exercise in futility. Why? Because such a tome is supposedly too long for students to read, even though the same instructors may routinely assign students more than 1,000 pages to read during a semester. Many students are savvy enough to recognize the syllabus ten pages as the most important ten pages of the course; those less savvy students we can enlighten didactically by explaining how milking the syllabus for all it's worth serves their best interests. In my introductory social science course, I give a syllabus quiz on the second day of class to highlight the status of the syllabus (I will send a copy of this 23-pager to anyone requesting it). Other ideas for making students conversant with the syllabus include placing them periodically in small groups to discuss certain parts of it; asking them to write brief reaction papers that analyze sections of the syllabus; and having them evaluate the syllabus by specifying what they like, dislike, and recommend for revision.

\section{Essential Elements of Sophisticated Sylaabi}

In the most comprehensive work to date on syllabi, Judith Grunert (1997) offers many useful suggestions, all of which advise that professors think through the content, as well as the process, before constructing their syllabi. Grunert envisions a reflective exercise powerful enough to improve courses by clarifying hidden beliefs and assumptions as part of a well-developed philosophical rationale for the course. The professor's unique academic soul should shine through in an elegant syllabus. Students benefit when they can glean from the syllabus exactly what it is that professors want them to be able to do and exactly how they will be assessed when they do it. Only by carefully planning a course can these lofty objectives come to fruition. What Grunert advocates might more ambitiously be called a course manual rather than a standard course syllabus. She looks with disfavor on documents skimmed over during the first class meeting and then filed away. Rather, she prefers dog-earred learning tools, use frequently as reference documents, that give more than mere information. Students should develop the habit of using these tools. Stripped to bare essentials, Grunert's ideal syllabus seeks to:

- Describe the course content, including its goals and objectives

- Describe the structure of the course and its significance within the general program of study 
- Discuss what mutual obligation students and instructors share

- Provide logistical as well as procedural information about what will happen, when, and where

Another useful model providing the nuts and bolts required to construct exemplary syllabi comes from Howard Altman and William Cashin (1992). They advocate building 11 components into the very architecture of the serious syllabus:

1) Course information: title, number, credits, prerequisites, location, meeting time

2) Instructor information: name, title, office number, hours, phone, email

3) Readings: textbook author, publisher, cost, why it was chosen, and how extensively it will be used, supplementary readings, and whether required or recommended

4) Course goals (more general) and student learning outcomes (more specific)

5) Course description: content of the course and how it fits into the broader curriculum

6) Instructional methods: the relative weight of respective pedagogical techniques (e.g., lecture, case study, small group discussion, values clarification, games, journal writing) should be explicated

7) Course calendar: a schedule (daily or weekly) of time structuring that identifies substance as well as dates for all assignments

8) Course policies: specific rules of the game concerning issues like attendance, tardiness, class participation, make-up exams, and plagiarism

9) Grading: how students will be evaluated, what factors will be included, their relative value, and how they will be tabulated into grades all resonate in the student psyche

10) Checklist: a listing of all course assignments at the end of document helps students keep track of what must be done and when

11) Support services: in what ways can the library, learning center, tutoring service, advising center, or computer center help students to succeed in this course? (Altman \& Cashin, 1992, pp. 3-4) 


\section{Heuristic Benefits of Sophisticated Syllabi}

First and foremost, fine syllabi serve to enhance student learning. Since college courses vary greatly, and since professors bring their uniqueness with them when they enter the classroom door, students don't really know what to expect during the pivotal first class session. Marie Birdsall (1989) cites research suggesting that the fear of the unknown produces anxious students on the first day of class. She argues that a thorough syllabus represents the best means of reducing student anxiety, thus launching the course in the right direction.

A thoughtful syllabus also works in a variety of more subtle ways: as a window revealing the philosophical disposition of the instructor; as a cognitive map showing why the intellectual terrain covered is important; as a model conveying to students the belief that planning has pedagogical value; as a contract binding the parties together; as a message that good teaching is important, and is facilitated by a model syllabus; as an antidote to the deterioration of communication between professor and student criticized above by Rubin; as testimony that excellent teachers have high expectations for themselves, as well as for their students; as a resource germane to the faculty evaluation process; and as the only substantive link between individual courses and the mission pursued by the wider curriculum. Diamond's book (1998) includes quotations taken from various professors who have reflected on the benefits flowing from their shift to a comprehensive syllabus. In the words of one instructor: "It helped a great deal. Faculty colleagues from other institutions have been able to easily adapt and adopt the course with limited guidance. In addition, I have very few requests for clarification of course requirements, time lines, grading criteria, or weekly assignments. Perhaps some faculty look forward to such repeated discussions-I prefer to teach" (Diamond, 1998, p. 195).

How the course syllabus can be used to improve teaching and to reduce time spent on housekeeping chores is easy to envision. But how the syllabus can aid in the evaluation of teaching remains somewhat opaque to many academic eyes. Too seldom do academic administrators conceptualize the syllabus as germane to assessing faculty performance. No department head would consider evaluating an untenured instructor without a class visit, and rightly so. But sometimes a sole visit becomes a pivotal event in evaluating an instructor, even though that session is not necessarily representative of the rest of the course. Administrators also ought to identify model syllabi and encourage faculty to emulate such documents. An elegant one operates as a nexus linking a class visit to the 
instructor's course objectives, readings, exams, and pedagogical techniques (which may differ from those of the evaluator). By discussing atypical techniques - such as group inquiry activities, writing across the curriculum or peer grading-the instructor can use the syllabus to explain why these methods make sense for this course.

Most experienced professors sense intuitively that when they plan ahead, organize their work well, and inform students exactly what they want, better teaching produces better learning. These hunches are confirmed in a recent study examining commonalties found among Carnegie Professors of the Year recognized by the Council for Advancement and Support of Education (CASE). University of Georgia management professor John Lough, who spawned the idea of dissecting the behavior of Carnegie Professors of the Year to see what makes them tick, set out to discover what in business studies is referred to as best practices benchmarking: in this context, behaviors associated with superior teaching.

One universal characteristic cited by Lough is that great teachers are very well organized, and their syllabi reflect this fact. The syllabi are written with rather detailed precision. Clearly stated course objectives and requirements are a hallmark. Typically, there is a precisely laid out day-byday schedule showing specific reading assignments as well as other significant requirements and due dates (Roth, 1996, p. 220). The editor of this fine volume, John Roth, Professor of Holocaust Studies at Claremont McKenna College, reinforces Lough's conclusion that great teachers are organized: they focus their concentration. Roth also notes that a broad, interdisciplinary curiosity characterizes Carnegie Professors of the Year, as does a love of research, dispelling the persistent myth that teaching and research are mutually exclusive. Outstanding teachers do not regard teaching and research as two separate activities. One informs the other (Roth, 1996, p. 227).

The solid planning endemic to exemplary syllabi can also yield dividends for both departmental and institutional curricula. This insight is driven home in one of the articles contributed to the Roth volume by 1994 Carnegie Professor of the Year Anthony Lisska, Professor of Philosophy and Director of the Honors Program at Denison University. Lisska emphasizes that curricular structures matter because they impact the learning process in profound ways. While neither as overt, nor as exciting, as the performance dimension to teaching, a rigorous syllabus enhances the academic structure which in turn enhances pedagogical success, and Lisska cites the honors program at Dension as illustrative. We don't immediately see the connections among curriculum, what curricu- 
lum structures enable us to do pedagogically, and how these structures assist in the development of the craft of teaching (Roth, 1996, p. 90). Professor Lisska's intriguing admonition that curricular structures (including fine syllabi) matter, should not be dismissed as too abstract to operationalize.

The potential exists for the course syllabus to forge substantive links between the three curricular levels of the academy that Diamond suggests often proceed in random directions: 1) the demonstration of quality teaching and learning in specific courses, 2) coherent and consistent programs of integrity at the departmental level, and, 3) institution-wide general studies requirements - all of which should contribute to the general mission statements of colleges and universities. Only by institutionalizing the sophisticated course syllabus can we aspire to connect individual courses to departmental programs to general studies to mission statements. Only comprehensive course syllabi provide detailed snapshots of what actually transpires inside the four walls of college classrooms. Only substantial course syllabi enable us to link intelligently the three different levels of curricular modernization now taking place in US higher education. And only dense course syllabi provide soft data to augment the hard data typically generated to satisfy contemporary demands for curricular accountability emanating from oversight bodies.

\section{Model Syllabi and Other Resources}

The West Virginia Consortium for Faculty and Course Development in International Studies (FACDIS) consists of 375 faculty members representing more than 15 disciplines and coming from all 20 institutions of higher education in West Virginia-public- and private-sector colleges, community colleges, and universities. For the past 20 years, the FACDIS statewide consortium has conducted numerous projects internationalizing the content of extant courses and creating new courses. FACDIS believes that solid course syllabi not only improve specific courses but also energize innovation in the general curriculum, and provide the mechanisms to make curricular reform accountable. Consequently, the consortium has overseen the transformation of hundreds of modest two-pagers into far more ambitious documents. While length alone may not constitute a sufficient condition for a dynamic course syllabus, it is nevertheless a necessary condition.

Similarly committed to rigorous course syllabi is the Semester at Sea program (SAS). Funded in part by the Institute for Shipboard Education, 
and based since 1980 at the University of Pittsburgh, SAS circles the globe twice annually with 600 students and 50 faculty and administrators aboard this sailing university. Academic courses in many disciplines are taught during 50 days at sea, and course-relevant field trips occur while visiting port cities. When I taught on the SAS faculty in 1990, professors had to submit detailed and defensible syllabi, since this unique program is routinely challenged to demonstrate the academic rigor of a floating campus visiting a dozen countries in four months. All syllabi required the approval of the relevant host department at the University of Pittsburgh before professors' courses were accepted into that semester's academic program. I read all course syllabi accepted for our voyage and found them to contain both depth and complexity.

Another organization that recognizes how excellent syllabi improve the curriculum is the Fund for the Improvement of Post-Secondary Education (FIPSE). From 1990-92, FIPSE funded a model syllabus program with the American Political Science Association (APSA), resulting in 11 monographs of 100-plus pages covering the discipline's key courses. Exemplary syllabi are solicited, veteran scholars select a few of the best ones, the editor writes a synthesis citing common themes among the elite syllabi, and the top syllabi are described and analyzed. The collection of syllabi for international relations, edited by Emory University's Linda Brady (1991), observes that those selected all present alternative theoretical perspectives, make theories concrete by using historical examples or case studies, keep students informed about contemporary affairs, and treat the course as a vehicle to develop research or writing skills. All of these APSA model syllabi collections can be found on the APSA website. Similarly, the American Sociological Association's website makes model syllabi readily available to interested faculty. Countless syllabi spanning both the humanities and social sciences can be easily accessed at $\mathrm{Hu}-$ manities-Net, and college and university syllabi from around the world are provided at Global Syllabi. Operating under the name of world lecture hall, an extensive site based at the University of Texas, Austin includes syllabi covering all academic disciplines (websites cited below).

A few creative syllabi caught my eye in one look around the Internet (see URL resources in endnotes). The syllabus for US Diplomatic History taught by Ernest Bolt at the University of Richmond is clear, concise, includes detailed assignments, encourages students to schedule conferences with him, and introduces each topic with pithy questions like: Why was Billy Joel interested in this subject? Did Harry Truman overreact in the Truman Doctrine speech? Would John Kennedy have pulled 
out of Vietnam had he lived longer? A rigorous, innovative, interdisciplinary undergraduate seminar is traced in Alix Cooper's Harvard University syllabus for Nature in Early Modern Europe and America. It begins by asking this intriguing question: What connection exists between the ways people have thought about nature and the way they have actually behaved towards it? An impressive reading list is given for each class period; activities for the last class are chosen by the students themselves.

While I have heard about courses taught completely online, I had no idea how one would be organized, until I read the syllabus for Charles Keyes' introductory philosophy course at Duquesne University. I was impressed by the inductive methodology allowing students to formulate their own answers to philosophical questions. Handwritten notebooks (substance) and journals (reactions) are submitted electronically, along with a term paper. Students have a chat-line to communicate with each other, and technical computer assistance is provided by trained course monitors. The final syllabus I selected because it illustrates something that administrators everywhere are now nudging faculty to introduce: capstone courses intended to tie together the experiences of an academic major. The capstone sociology course at Duke University taught by Kenneth Spenner explains the rationale behind the capstone concept, employs an engaging case study project for student participation, places students in teams for other projects, and uses current events as a way to relate engagingly concepts learned in prior courses to contemporary real world occurrences.

\section{Conclusion}

An authority on American higher education, Robert Diamond, points to cracks in the curricular foundation at three levels of the academy (individual course, departmental major, institutional general studies program). It is suggested here that the sophisticated course syllabus, often overlooked in academia, can assist efforts to restore curricular integrity. Not only do model syllabi improve teaching and learning in individual courses, they can also enlist all three levels of the curriculum in furthering the mission statements that constitute higher education's blueprint. If conceptualized more complexly, the course syllabus has the potential to broaden the base of curricular accountability called for by the assessment movement which currently occupies center stage in higher education. 


\section{REFERENCES}

Altman H., \& Cashin, W. C. (1992, September). Writing a syllabus. Manhattan, KS: Kansas State University, Center for Faculty Evaluation and Development.

Birdsall, M. (1989). Writing, designing, and using a course syllabus. Boston, MA: Northeastern University, Office for Effective Teaching.

Brady, L. (1991). Political science course syllabi collection: International Relations. Washington, DC: American Political Science Association.

Diamond, R. (1998). Designing and assessing courses and curricula: A practical guide. San Francisco, CA: Jossey-Bass.

Grunert, J. (1997). The course syllabus: A learning-centered approach. Bolton, MA: Anker.

Roth, J. K. (Ed.) (1996). Inspiring teaching: Carnegie professors of the year speak. Bolton, MA: Anker.

Rubin, S. (1985, August). Professors, students, and the syllabus. Chronicle of Higher Education, 7, p. 56.

\section{INTERNET ENDNOTES}

The following URLs carry examples of outstanding syllabi representing various disciplines:

The Humanities (H-net)

http://www.h-net2.msu.edu/ aseh/syllabi/

World Lecture Hall

http://www.vcu.edu/mdcweb/english/

American Political Science Association Model Syllabi Project

http://www.apsanet.org/teaching/syllabi/APSA/

Global Syllabi

http://www.ecnet.net/users/bigOama/syllabi/syllabi.html

American Sociological Association

http://www.asanet.org/pubs/tchgres.htm

EdWeb

http://www.edweb.cnidr.org:90/ 
Virtual Classroom

http://www.enmu.edu/virtual/virt.html

Developing Educational Standards: Overview

http://www.putwest.boces.org/standards.html

The Global Campus

http://www.csulb.edu/gc/

WebEd Curriculum Links

http://www.badger.state.wi.us/agencies/dpi/www/WebEd.html

Courseware for Higher Education on the World Wide Web

http://www.philae.sas.upenn.edu

AskERIC

http://www.erieir.syr.edu

Syllabus Web

http://www.syllabus.com

Ernest Bolt Syllabus

http://www.richmond.edu/ ebolt/syll327.html

Alix Cooper Syllabus

http://www.h-net2.msu.edu/ aseh/syllabi/cooper.htm

Charles Keyes Syllabus

http://www.duq.edu/ keyes/bpq/syllabus.html

Kenneth Spenner Syllabus

http://www.soc.duke.edu/courses/soc190_syl_f96.html

\section{Contact:}

Michael J. Strada, Professor of Political Science

West Liberty State College

Visiting Professor and FACDIS Co-Director,

Department of Political Science, P.O. Box 6317

West Virginia University

Morgantown, WV 26506-6317

(304) 293-7140

Email:mjstrada@cs.com 
Michael Strada has taught international studies courses at West Liberty State College since 1969 and at West Virginia University since 1985. At WVU he serves as co-director of the statewide international studies consortium known as FACDIS. Strada's recent publications include an Through the Global Lens: An introduction to the social sciences (Prentice Hall, 1999), a scholarly book on Russians in American film and foreign policy, and an article in USA Today on political movies. The subject of his current research is Americanadians: draft evaders who moved to Canada during the Vietnam War. In 2000 he won the West Liberty State Excellence in Professional Activity award for the third time and was selected a spring commencement speaker. In the preface to his textbook, he says that he "is actively involved in his grandsons' athletic teams because he believes that sports teach a work ethic, and that the extended Strada family's rituals of choice revolve around sports." His grandsons compete in baseball, soccer, and hockey and he tries in vain to keep up with them. 